\title{
Developing and Validating Instrument of Career Decision of Islamic Senior High School Students in Yogyakarta, Indonesia
}

\author{
Arintiya Nadia Arini ${ }^{1}$, Edi Purwanta ${ }^{2}$, Nur Hidayat ${ }^{3 *}$ \\ ${ }^{1,2}$ Universitas Negeri Yogyakarta, Indonesia, ${ }^{3}$ STKIP Bina Insan Mandiri, Indonesia \\ *e-mail: nurhidayat@ stkipbim.ac.id
}

\begin{abstract}
This study aimed to develop and validate an instrument of career decision of senior high level. Two hundred thirty-three learners from one of the Islamic senior high schools in Yogyakarta were involved in this study. The design of this study was research and development ( $R \& D)$, which consisted of eight steps: a) identifying the purpose of measuring, $b$ ) domain restriction of measuring, $c$ ) operationalization of aspects, d) item writing, e) language trial, and field test, f) item selection, $g$ ) construct validation, and h) final validation. The researcher implicated students and expert judgments to validate the instrument. A small group and large group instrument try-out were done in this study. To analyze the data, the researcher combined the statistical calculation and confirmatory factor analysis (CFA). The result of this study showed that the career decision instrument undergoes some revision before it was fixed. The expert's judgments \& result of the small group tryout showed that the instruments must be improved. The researcher revised some items in the instrument and did the large group try-out. The result of confirmatory factor analysis indicated that the career decision instrument was fixed. It was ready to use by the counseling teachers to help the senior high school students make career decisions for their future.
\end{abstract}

Keywords:

Developing; Validating; Instrument; Career Decision; Senior High Level

\begin{abstract}
ABSTRAK
Penelitian ini bertujuan untuk mengembangkan dan memvalidasi instrumen keputusan karir SMA. Dua ratus tiga puluh tiga peserta didik dari salah satu SMA Islam di Yogyakarta dilibatkan dalam penelitian ini. Rancangan penelitian ini adalah penelitian dan pengembangan $(R \& D)$, yang terdiri dari delapan langkah: a) mengidentifikasi tujuan pengukuran, b) pembatasan domain pengukuran, $c$ ) operasionalisasi aspek, d) penulisan item, e) uji coba bahasa, dan uji lapangan, f) pemilihan item, g) validasi konstruk, dan $h$ ) validasi akhir. Peneliti
\end{abstract}


mengimplikasikan penilaian siswa dan ahli untuk memvalidasi instrumen. Uji coba instrumen kelompok kecil dan kelompok besar dilakukan dalam penelitian ini. Untuk menganalisis data, peneliti menggabungkan perhitungan statistik dan analisis faktor konfirmatori (CFA). Hasil penelitian menunjukkan bahwa instrumen keputusan karir mengalami beberapa revisi sebelum ditetapkan. Penilaian ahli \& hasil uji coba kelompok kecil menunjukkan bahwa instrumen harus ditingkatkan. Peneliti merevisi beberapa item dalam instrumen dan melakukan uji coba kelompok besar. Hasil analisis faktor konfirmatori menunjukkan bahwa instrumen keputusan karir sudah diperbaiki. Itu siap digunakan oleh para guru konseling untuk membantu siswa sekolah menengah atas membuat keputusan karir untuk masa depan mereka.

\section{Kata Kunci:}

Pengembangan; Validasi; Instrumen; Keputusan Karir; Level Sekolah Menengah Atas

\section{Introduction}

Adolescence is one of the markers of a person's entry into the adult lifestyle. Youth is a transition from child to adult. As individuals undergoing the transition process, they have developmental tasks that lead to their readiness to meet adulthood's demands and expectations (Suherman, 2013). Senior high school students are adolescents who are ready to face the career (Atmaja, 2014). In this phase, they develop in all parts of the physical and thought towards maturity. The developmental phase of adolescence is influenced by social, emotional, and physical aspects. Besides, youth have developmental tasks that lead to preparation to meet adults' demands and roles (Hurlock, 1993). At this stage, one of the functions of youth development is choosing and preparing to carry out a job and think about the career that will be pursued in the future (Sharf, 2016).

Careers become part of adult life that affects the happiness of every human being. Therefore, choosing a future career becomes essential in human life, especially in adolescence, who still sit in high school. In adolescence, school is an important aspect to help prepare for future careers, this is in the opinion of Seligman (1994) that a number of careers began to be built and developed from school, and a career can also be said as a desirable goal, whether related to an education, a job or a particular profession (Pinasti, 2011).

Students' career problems often arise when they have not received optimal service in career guidance. Career information services are urgently needed in preparing students' careers and making career decisions. However, many counseling teachers are difficult to guide them in determining their future careers because of the minimum career decision development (Buldur \& Bursal, 2015). It is confirmed by Prambudi's (2015) findings which report that the minimum career decision instruments in Indonesia cause the counseling teachers difficulties to lead students' career decision problems.

Mentoring and counseling teachers have an essential role in helping students gather data and information to make their career decisions appropriately and quickly (Storme \& Celik, 2018). One 
way that can be done is by giving instruments ( $\mathrm{Xu}$ et al, 2014). The purpose of providing the instrument is to be used as a benchmark for guidance and counseling teachers in providing career information that includes the most basic needs that students need in making their career decisions (Artosandi, 2014).

The lack of career decision-making instruments resulted in a lack of guidance and counseling teachers informing students about their careers, resulting in them being less than optimal in making career decisions for their future (Buldur \& Bursal, 2015). Prambudi's findings (2015) report that only $57 \%$ of senior high school students determine their career decision based on their interests. Moreover, $63 \%$ of students are not yet sure of their own decisions about their career decision.

Those findings indicate that problems that arise due to the lack of instruments for career decision-making have not been widely developed in Indonesia, so guidance and counseling teachers still have difficulty using or developing the services performed. It is necessary to use easy-to-use guidance and counseling teachers available in the context of Indonesia. Instrument development is expected to assist teachers in providing appropriate information around work and further education tailored to student's characteristics, interests, and values (Curry \& Amy Milsom, 2017).

The development of the instrument needs to go through the assessment stage included in career decision-making instruments. According to Wood \& Hays (2013), the assessments based on goal categories and career decision-making factors are influenced by the environment and information about the work that students want. In some developed countries, the development of career decisionmaking instruments is essential. It becomes a need for counseling guidance teachers, in contrast to the mining needs of career decision-making instruments in Indonesia, which have not been explicitly developed to measure students' ability to make career decisions. In American schools, the use of career decision-making instruments is a tool used to gather information for individual or group decision-making systematically (Curry \& Amy Milsom, 2017). In contrast to the development of career decision-making instruments developed in Turkey, career decision-making instruments are given to high school students. It aims to help students outline their difficulties in making future career decisions (Kirdök \& Harman, 2018).

Based on the mining of emerging career decision-making instruments in different countries, the researcher intends to develop a standard career decision instrument. It must be based on factors that influence future career choices and avoid biases on differences and uncover students' difficulty in choosing their careers. This career decision-making instrument's focus is to assist guidance and counseling teachers in schools in preparing for students' future by providing materials and discussing relevant issues.

\section{Method}

The research design of this study adopted the research and design (R\&D) model by Azwar (2014), which consisted of eight steps; a) identifying the purpose of measuring, b) domain restriction 
of measuring, c) operationalization of aspects, d) item writing, e) language trial and field test, f) item selection, g) construct validation, and h) final validation. This study aimed to develop and validate the instrument of career decision to help senior high school students determine their future careers.

The participants of this study were 233 learners of one Islamic senior high school in Yogyakarta. To validate the development of the career decision instrument, the researchers involved two experts in educational counseling with a doctoral degree and more than ten years of experience. The researchers also implicated students in doing instrument try-out to strengthen career decision instrument's validity and reliability.

\subsection{Types of Data and Instruments}

In this study, the researcher used two groups of data, qualitative and quantitative data. The qualitative data were obtained from the results of experts' judgments of the career decision instruments. The quantitative data were in the form of a career decision scale validated and relied on by the instrument validation. All of those data were collected and validate through eight steps of developing students' career decision adopted from Azwar (2014), they were: a) identifying the purpose of measuring, b) domain restriction of measuring, c) operationalization of aspects, d) item writing, e) language trial and field test, f) item selection, g) construct validation, and h) final validation adopted from Azwar (2015) were used in the process of developing career decision instrument for senior high school students. The first until the fourth step in developing career decision instruments were identifying the purpose of measuring and b) domain restriction of measuring, c) operationalization of aspects, and d) item writing. The researcher collected all components and information related to career decisions based on the psychological theory and instrument developed by Kirdök \& Harman (2018). After that, the researcher constructed the scale's items based on the aspects and indicators and wrote them. In this section, the researcher constructed the scale's items based on two aspects (internal and external) and five indicators (self condition, self-experience, ability to manage information, education level, family, environmental condition, and coping and culture), which contained 79 items (see appendix 1).

Next, the researcher did the fifth until eighth steps (language trial and field test, item selection, construct validation, and final validation). The researcher delivered a career decision scale to the expert in these steps to get the judgment and suggestion. It was delivered to two people with doctoral degrees who experts in psychology education and language. After getting the expert's judgment and suggestions, the researcher revised the items and confirmed them to the expert again to make sure they were legitimate. Then, the researcher delivered them to a small group that involved 32 students of senior high school. The researcher asked them to answer all items honestly. Students' answers and expert's judgments were confirmed to select the career decision items until got the fixed items that will be delivered to the students in the big group. Those steps were included in language trial and field test and item selection steps. After that, the researchers did the construct validation and final validation by delivering the fix items to the big group, which consisted of 233 students. The result of students' answers was analyzed by statistical calculation using Lisrel. Next, the researchers selected 
the valid items related to the result of Confirmatory Factor Analysis (CFA) and wrote the items in the form of a table.

The instruments used by the researchers in this study were the experts' judgment and career decision scale. The researcher used the grille of career decision scale instrument, which consists of 2 factors; internal and external factors. The experts gave judgments to it with the total of fit items. Besides, they also gave suggestions about the instruments, which became the fundamental element to revise the career decision instrument. To validate and rely on the career decision instrument, the researchers did the instrument try-out by delivering them to the expert, the small group, and the big group of the students in an Islamic senior high school in Yogyakarta.

\subsection{Data Analysis}

To analyze the data, the researchers classified the data into qualitative and quantitative data. The qualitative data consisted of the experts' suggestions about the career decision instrument. The quantitative information consists of the results of the instrument judgments by experts (scores of the grille instruments) and the result of instrument try-out. The researchers analyzed the qualitative data by transcribing the data while the quantitative data analyzed by statistical calculation and Lisrel through Confirmatory Factor Analysis. Last, the researchers analyzed and compared the result from the qualitative and quantitative data, and then the researcher made the conclusion.

\section{Results and Discussion}

The expert's judgments of the career decision instruments described that 79 items of career decision instruments were good. However, there are three points that must be revised to improve the career decision instruments: the appropriateness, the context, and the language of the items. A clear explanation about them was described in Table 1.

Table 1. The Summary of the Career Decision Instruments Being Developed

\begin{tabular}{|c|c|c|c|}
\hline \multirow[b]{2}{*}{ Aspects } & \multirow[b]{2}{*}{ Indicator } & \multicolumn{2}{|c|}{ Total of the questions } \\
\hline & & $\begin{array}{c}\text { Favourable } \\
(+)\end{array}$ & $\begin{array}{c}\text { Unfavourable } \\
(-)\end{array}$ \\
\hline \multirow{3}{*}{$\begin{array}{l}\text { Internal } \\
\text { Factors }\end{array}$} & Self Condition & 6 & 4 \\
\hline & Self Experience & 8 & 3 \\
\hline & Ability to manage information & 11 & 1 \\
\hline \multirow{5}{*}{$\begin{array}{l}\text { External } \\
\text { Factors }\end{array}$} & Education Level & 9 & 2 \\
\hline & Family & 7 & 4 \\
\hline & Environmental Condition & 4 & 8 \\
\hline & Coping and Culture & 9 & 3 \\
\hline & Total item & \multicolumn{2}{|c|}{79} \\
\hline
\end{tabular}


Table 2. The Expert's Suggestions

\begin{tabular}{cc}
\hline No & Suggestions \\
\hline 1 & Some items are not appropriate with the aspects and indicators. \\
2 & The sentences must be adjusted based on the context \\
3 & Some ambiguous items must be changed into clear sentences \\
\hline
\end{tabular}

Based on table 2, the expert gave three suggestions that the researchers must revise to make the career decision instrument better. After getting the expert's suggestion, the researcher revised those items to improve the decision career instrument. Next, the researcher gave the revision to the expert again to make sure that the career decision instrument was fixed and ready to spread to the small group. The purpose of this action was to make sure that the items of students' career decision instruments were ready to deliver to the small group and to confirm the language trial and item selection steps.

Table 3. The Result of Career Decision Instrument Try-out in Small Group

\begin{tabular}{|c|c|c|c|c|c|c|c|c|}
\hline No & & $\begin{array}{l}\text { Corrected } \\
\text { Item-Total } \\
\text { Correlation }\end{array}$ & & $\begin{array}{l}\text { Corrected } \\
\text { Item-Total } \\
\text { Correlation }\end{array}$ & & $\begin{array}{l}\text { Corrected } \\
\text { Item-Total } \\
\text { Correlation }\end{array}$ & & $\begin{array}{l}\text { Corrected } \\
\text { Item-Total } \\
\text { Correlation }\end{array}$ \\
\hline 1 & $\begin{array}{l}\text { VA } \\
\text { R01 }\end{array}$ &,- 274 & $\begin{array}{r}\text { VA } \\
\text { R021 }\end{array}$ & $.965^{* *}$ & $\begin{array}{l}\text { VAR0 } \\
41\end{array}$ & $.993^{* *}$ & $\begin{array}{l}\text { VAR } \\
061\end{array}$ & $.996^{* *}$ \\
\hline 2 & $\begin{array}{l}\text { VA } \\
\text { R02 }\end{array}$ &,- 101 & $\begin{array}{r}\text { VAR } \\
022\end{array}$ & $.953^{* *}$ & $\begin{array}{l}\text { VAR } \\
042\end{array}$ & $.995^{* *}$ & $\begin{array}{l}\text { VAR } \\
062\end{array}$ & $.996^{* *}$ \\
\hline 3 & $\begin{array}{l}\text { VA } \\
\text { R03 }\end{array}$ & ,133 & $\begin{array}{r}\text { VAR } \\
023\end{array}$ & $.977^{* *}$ & $\begin{array}{l}\text { VAR } \\
043\end{array}$ & $.996^{* *}$ & $\begin{array}{l}\text { VAR } \\
063\end{array}$ & $.996^{* *}$ \\
\hline 4 & $\begin{array}{l}\text { VA } \\
\text { R04 }\end{array}$ & ,259 & $\begin{array}{r}\text { VAR } \\
024\end{array}$ & $.969^{* *}$ & $\begin{array}{l}\text { VAR } \\
044\end{array}$ & $.990^{* *}$ & $\begin{array}{l}\text { VAR } \\
064\end{array}$ & $.997^{* *}$ \\
\hline 5 & $\begin{array}{l}\text { VA } \\
\text { R05 }\end{array}$ & $.430^{*}$ & $\begin{array}{l}\text { VAR } \\
025\end{array}$ & $.987^{* *}$ & $\begin{array}{l}\text { VAR } \\
045\end{array}$ & $.994^{* *}$ & $\begin{array}{l}\text { VAR } \\
065\end{array}$ & $.998^{* *}$ \\
\hline 6 & $\begin{array}{l}\text { VA } \\
\text { R06 }\end{array}$ & $.609^{* *}$ & $\begin{array}{l}\text { VAR } \\
026\end{array}$ & $.989^{* *}$ & $\begin{array}{l}\text { VAR } \\
046\end{array}$ & $.998^{* *}$ & $\begin{array}{l}\text { VAR } \\
066\end{array}$ & $.998^{* *}$ \\
\hline 7 & $\begin{array}{l}\text { VA } \\
\text { R07 }\end{array}$ & $.609^{* *}$ & $\begin{array}{l}\text { VAR } \\
027\end{array}$ & $.978^{* *}$ & $\begin{array}{l}\text { VAR } \\
047\end{array}$ & $.994^{* *}$ & $\begin{array}{l}\text { VAR } \\
067\end{array}$ & $.996^{* *}$ \\
\hline 8 & $\begin{array}{l}\text { VA } \\
\text { R08 }\end{array}$ & $.693^{* *}$ & $\begin{array}{l}\text { VAR } \\
028\end{array}$ & $.992^{* *}$ & $\begin{array}{l}\text { VAR } \\
048\end{array}$ & $.994^{* * *}$ & $\begin{array}{l}\text { VAR } \\
068\end{array}$ & $\begin{array}{l}* \\
.997^{* *}\end{array}$ \\
\hline 9 & $\begin{array}{l}\text { VA } \\
\text { R09 }\end{array}$ & $.752^{* * *}$ & $\begin{array}{l}\text { VAR } \\
029\end{array}$ & $.977^{* *}$ & $\begin{array}{l}\text { VAR } \\
049\end{array}$ & $.993^{* *}$ & $\begin{array}{l}\text { VAR } \\
069\end{array}$ & $.995^{* *}$ \\
\hline 10 & $\begin{array}{l}\text { VA } \\
\text { R10 }\end{array}$ & $.779^{* *}$ & $\begin{array}{l}\text { VAR } \\
030\end{array}$ & $.986^{* *}$ & $\begin{array}{l}\text { VAR } \\
050\end{array}$ & $.994^{* *}$ & $\begin{array}{l}\text { VAR } \\
070\end{array}$ & $.997^{* *}$ \\
\hline 11 & $\begin{array}{l}\text { VA } \\
\text { R01 } \\
1\end{array}$ & $.819^{* *}$ & $\begin{array}{l}\text { VAR } \\
031\end{array}$ & $.995^{* *}$ & $\begin{array}{l}\text { VAR } \\
051\end{array}$ & $.994^{* * *}$ & $\begin{array}{l}\text { VAR } \\
071\end{array}$ & $.998^{* *}$ \\
\hline 12 & $\begin{array}{l}\text { VA } \\
\text { R01 } \\
2\end{array}$ & $.858^{* *}$ & $\begin{array}{l}\text { VAR } \\
032\end{array}$ & $.983^{* *}$ & $\begin{array}{l}\text { VAR } \\
052\end{array}$ & $.996^{* * *}$ & $\begin{array}{l}\text { VAR } \\
072\end{array}$ & $.995^{* * *}$ \\
\hline
\end{tabular}




\begin{tabular}{|c|c|c|c|c|c|c|c|c|}
\hline 13 & $\begin{array}{l}\text { VA } \\
\text { R01 } \\
3\end{array}$ & $.892^{* *}$ & $\begin{array}{l}\text { VAR } \\
033\end{array}$ & $.993^{* *}$ & $\begin{array}{l}\text { VAR } \\
053\end{array}$ & $.996^{* *}$ & $\begin{array}{l}\text { VAR } \\
073\end{array}$ & $.998^{* *}$ \\
\hline 14 & $\begin{array}{l}\text { VA } \\
\text { R01 } \\
4\end{array}$ & $.892^{* *}$ & $\begin{array}{l}\text { VAR } \\
034\end{array}$ & $.995^{* * *}$ & $\begin{array}{l}\text { VAR } \\
054\end{array}$ & $.997^{* * *}$ & $\begin{array}{l}\text { VAR } \\
074\end{array}$ & $.998^{* *}$ \\
\hline 15 & $\begin{array}{l}\text { VA } \\
\text { R } \\
015\end{array}$ & $.892^{* *}$ & $\begin{array}{l}\text { VAR } \\
035\end{array}$ & $.991^{* *}$ & $\begin{array}{l}\text { VAR } \\
055\end{array}$ & $.996^{* *}$ & $\begin{array}{l}\text { VAR } \\
075\end{array}$ & $.997^{* *}$ \\
\hline 16 & $\begin{array}{l}\text { VA } \\
\text { R } \\
016\end{array}$ & $.935^{* *}$ & $\begin{array}{l}\text { VAR } \\
036\end{array}$ & $.991^{* *}$ & $\begin{array}{l}\text { VAR } \\
056\end{array}$ & $.996^{* *}$ & $\begin{array}{l}\text { VAR } \\
076\end{array}$ & $.998^{* *}$ \\
\hline 17 & $\begin{array}{l}\text { VA } \\
\text { R } \\
017\end{array}$ & $.922^{* *}$ & $\begin{array}{l}\text { VAR } \\
037\end{array}$ & $.992^{* *}$ & $\begin{array}{l}\text { VAR } \\
057\end{array}$ & $.994^{* *}$ & $\begin{array}{l}\text { VAR } \\
077\end{array}$ & $.997^{* *}$ \\
\hline 18 & $\begin{array}{l}\text { VA } \\
\text { R } \\
018\end{array}$ & $.918^{* *}$ & $\begin{array}{l}\text { VAR } \\
038\end{array}$ & $.991^{* * *}$ & $\begin{array}{l}\text { VAR } \\
058\end{array}$ & $.995^{* *}$ & $\begin{array}{l}\text { VAR } \\
078\end{array}$ & $.997^{* *}$ \\
\hline 19 & $\begin{array}{l}\text { VA } \\
\text { R } \\
019\end{array}$ & $.926^{* *}$ & $\begin{array}{l}\text { VAR } \\
039\end{array}$ & $.991^{* *}$ & $\begin{array}{l}\text { VAR } \\
059\end{array}$ & $.997^{* *}$ & $\begin{array}{l}\text { VAR } \\
079\end{array}$ & $.997^{* *}$ \\
\hline 20 & $\begin{array}{l}\text { VA } \\
\mathrm{R} \\
020\end{array}$ & $.971^{* *}$ & $\begin{array}{l}\text { VAR } \\
040\end{array}$ & $.991^{* *}$ & $\begin{array}{l}\text { VAR } \\
060\end{array}$ & $.997^{* *}$ & & \\
\hline
\end{tabular}

Based on the result above, the researcher found that four items were not valid in the first indicator (item numbers 1, 2, 3, and 4). It meant only 75 items that were valid and were able to use in instruments try-out in the large group. This step was still under the field items selection step. Afterward, the researcher continued the step to the construct validation and final validation by delivered the 75 items to the large group, which consisted of 322 students. The purpose of this step was to measure the validity level of the instrument. To measure it, the researcher used Confirmatory Factor Analysis (CFA) through Lisrel V8.50. The result was presented in Figure 1.

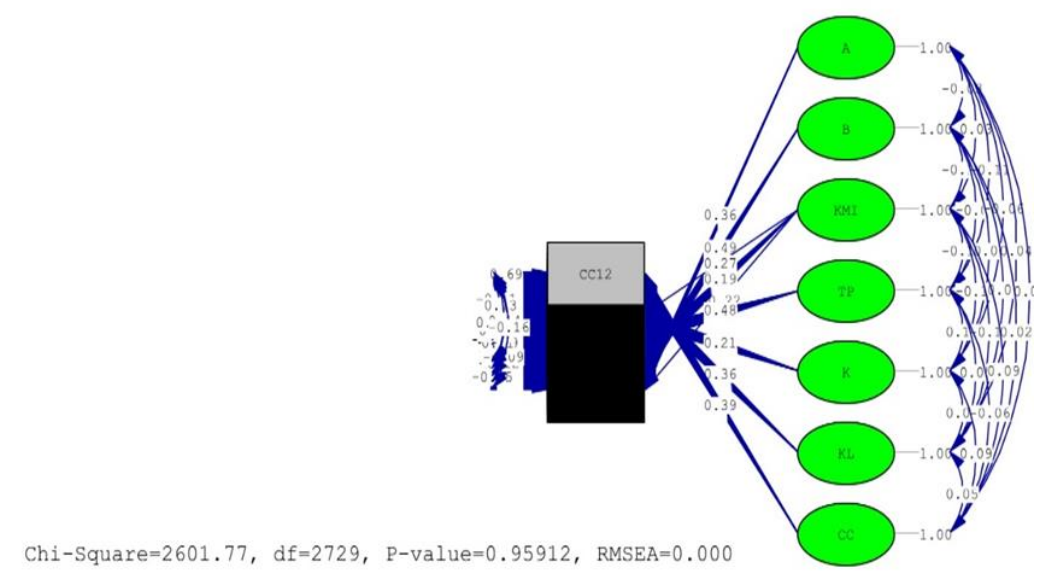

Figure 1. The Result of Confirmatory Factor Analysis (CFA 
To get the fit of the instrument, the result must fill the main criteria: Chi-Square: $p>0.05$, RSMEA < 0.005. Diagram 1 showed the result of Chi-Square: 2601.77, df: 2729, p-value: 0.95912 and RMSEA: 0.000. This finding indicated that the instrument was fit. It revealed that 75 items were valid and reliable.

The result revealed that the career decision instrument was valid and reliable. It was proved by the process of developing it, which consisted of eight steps. It is also supported by the result of expert's judgments, expert's suggestion, instrument try-out in the small \& large groups. Moreover, the statistical calculation and confirmatory factor analysis indicated that the career decision instrument was fit and acceptable. The result of it became the final validation in this step. The result of the students' career decision instruments was presented in Appendix 1.

\section{Conclusions}

The development of a career decision instrument was done to fulfill the senior high school students' needs to determine their career decision. It also assisted the counseling teacher in accompanying their students to plan their career decision in the future. In developing the career decision instrument, the researcher did eight steps to process it to be valid \& reliable. Moreover, the expert's judgment, small group try-out, and large group try-out of the instrument were performed to bring it to be a fit instrument. Based on the findings, the items of it were revised, and four of them were deleted. It meant that only 75 items from 79 items if it was valid, reliable, and fit. The researcher concluded that 75 items of career decision instrument were distributed by the counseling teachers to their students (senior high level).

\section{References}

Artosandi, Y. S. R. (2014). Pengembangan Instrumen Minat Vokasional Berbasis Tipologi Holland untuk Eksplorasi Karir Siswa Sekolah Menengah Pertama.

Atmaja, T. T. (2014). Upaya meningkatkan perencanaan karir siswa melalui bimbingan karir dengan penggunaan media modul. Psikopedagogia, 3(2), 58-68.

Azwar, S. (2014). Metode Penelitian. In Reliabilitas dan Validitas Edisi (Vol. 4). Yogyakarta: Pustaka Pelajar.

Buldur, S., \& Bursal, M. (2015). The impact levels of career choice reasons of preservice science teachers and their future career expectations. Necatibey Eğitim Fakültesi Elektronik Fen ve Matematik Eğitimi Dergisi [Necatibey Faculty of Education Electronic Journal of Science \& Mathematics Education], 9(1), 81-107.

Curry, J. R., \& Amy Milsom, De. (2017). Career and college readiness counseling in P-12 schools. Springer Publishing Company.

Hurlock, E. B. (1993). Suatu pendekatan Sepanjang Rentang Kehidupan.(edisi ke 5). In Erlangga, Jakarta. Erlangga. 
Kirdök, O., \& Harman, E. (2018). High School Students' Career Decision-Making Difficulties According to Locus of Control. Universal Journal of Educational Research, 6(2), 242-248.

Pinasti, W. (2011). Pengaruh self-efficacy, locus of control dan faktor demografis terhadap kematangan karir mahasiswa UIN Syarif Hidayatullah Jakarta (Skripsi). Jakarta: UIN Syarif Hidayatullah Jakarta.

Prambudi, H. (2015). Kemampuan pengambilan keputusan karir siswa kelas XI di SMA Negeri 1 Kutasari Purbalingga. Jurnal Riset Mahasiswa Bimbingan Dan Konseling, 4(4), 1-16.

Seligman, L. (1994). Developmental career counseling and assessment. Thousand Oaks, California: Sage Publications, Inc.

Sharf, R. S. (2016). Applying career development theory to counseling. Nelson: Nelson Education.

Storme, M., \& Celik, P. (2018). Career exploration and career decision-making difficulties: The moderating role of creative self-efficacy. Journal of Career Assessment, 26(3), 445-456.

Suherman, U. (2013). Konseling karir sepanjang rentang kehidupan. Bandung: Sekolah Pascasarjana UPI Bandung.

Wood, C., \& Hays, D. G. (2013). A counselor's guide to career assessment instruments. ERIC.

Xu, H., Hou, Z.-J., \& Tracey, T. J. G. (2014). Relation of environmental and self-career exploration with career decision-making difficulties in Chinese students. Journal of Career Assessment, $22(4), 654-665$. 


\section{Appendix 1. The Students' Career Decision Instruments.}

(Instruments number 1 until 4 are invalid).

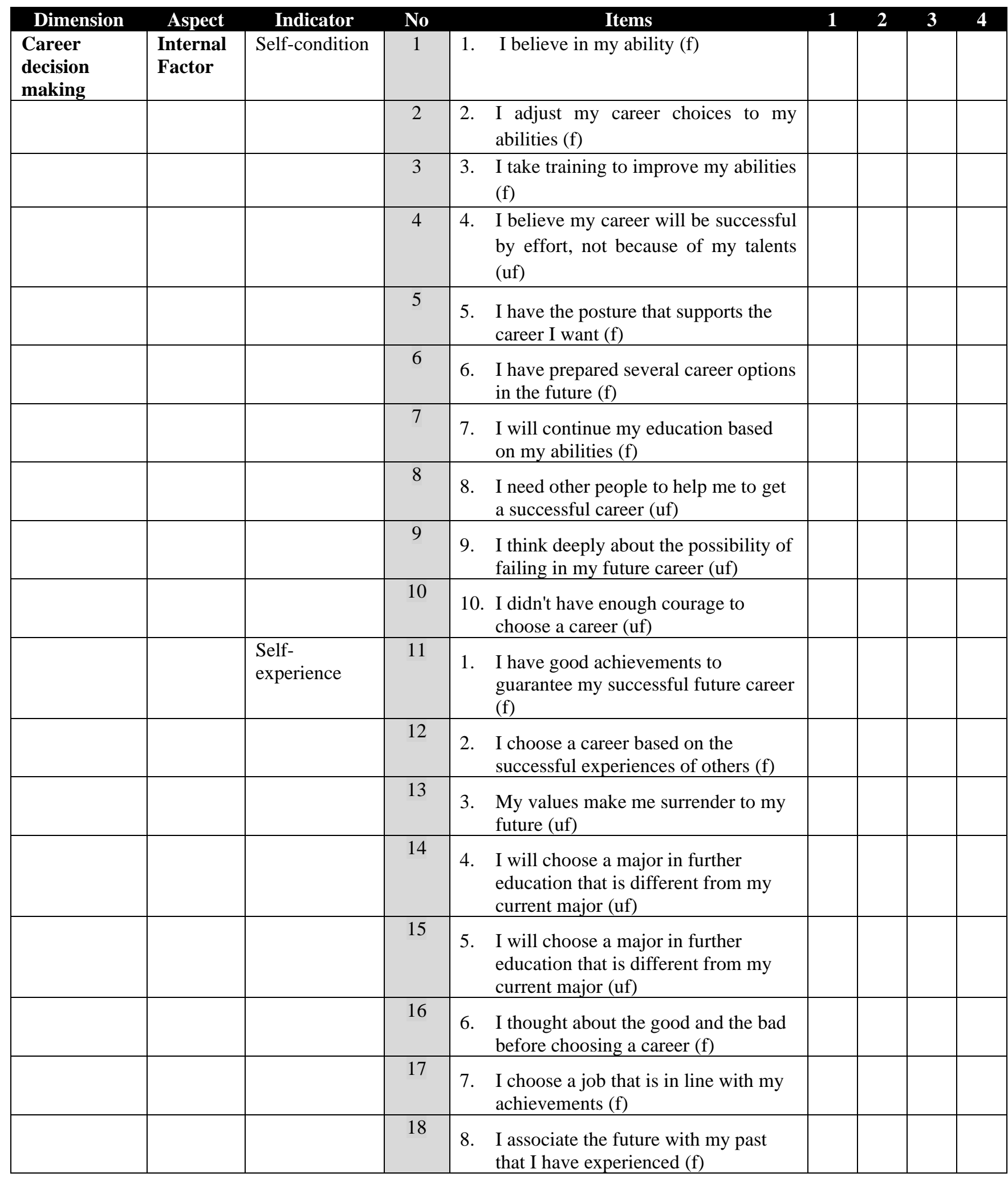




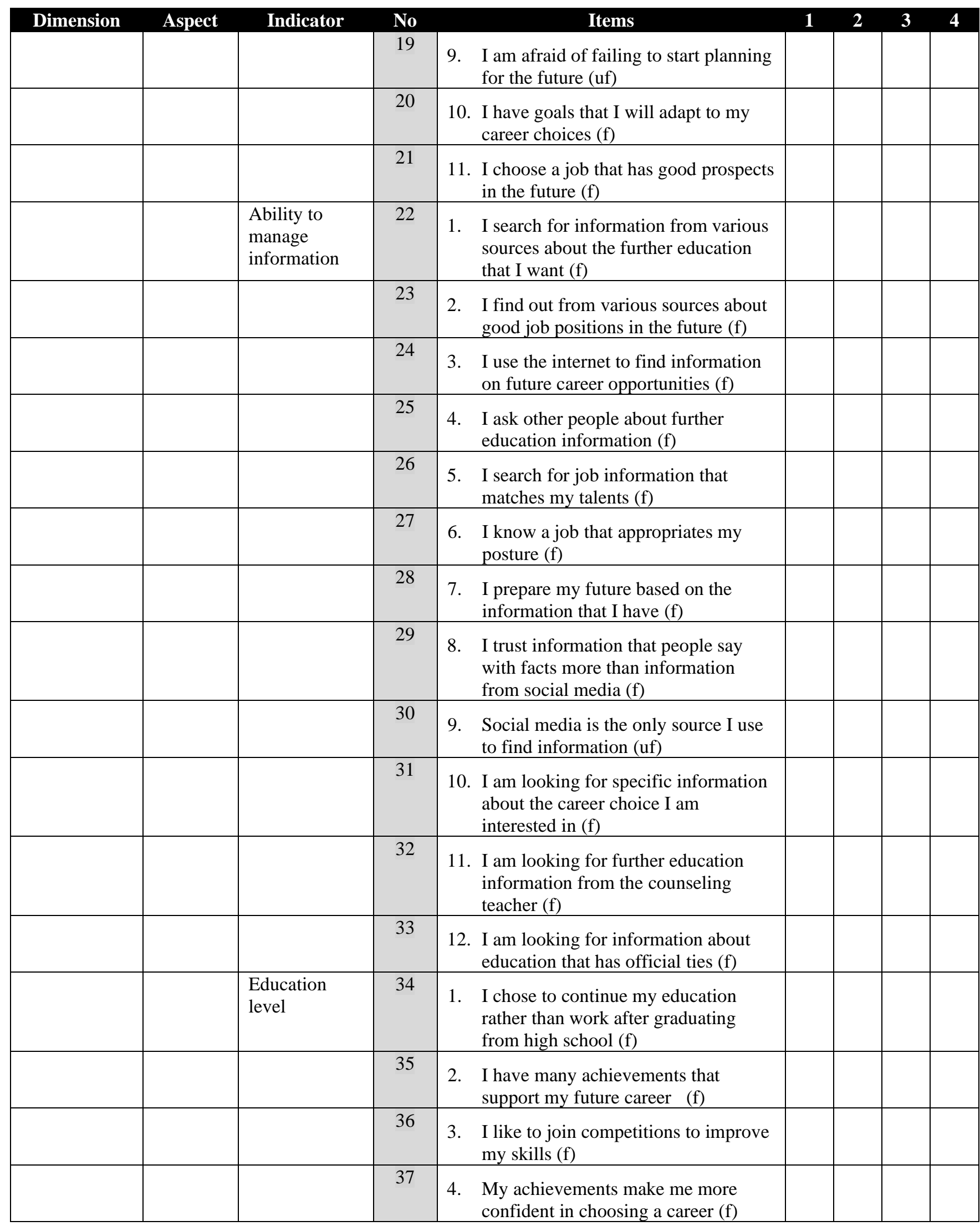




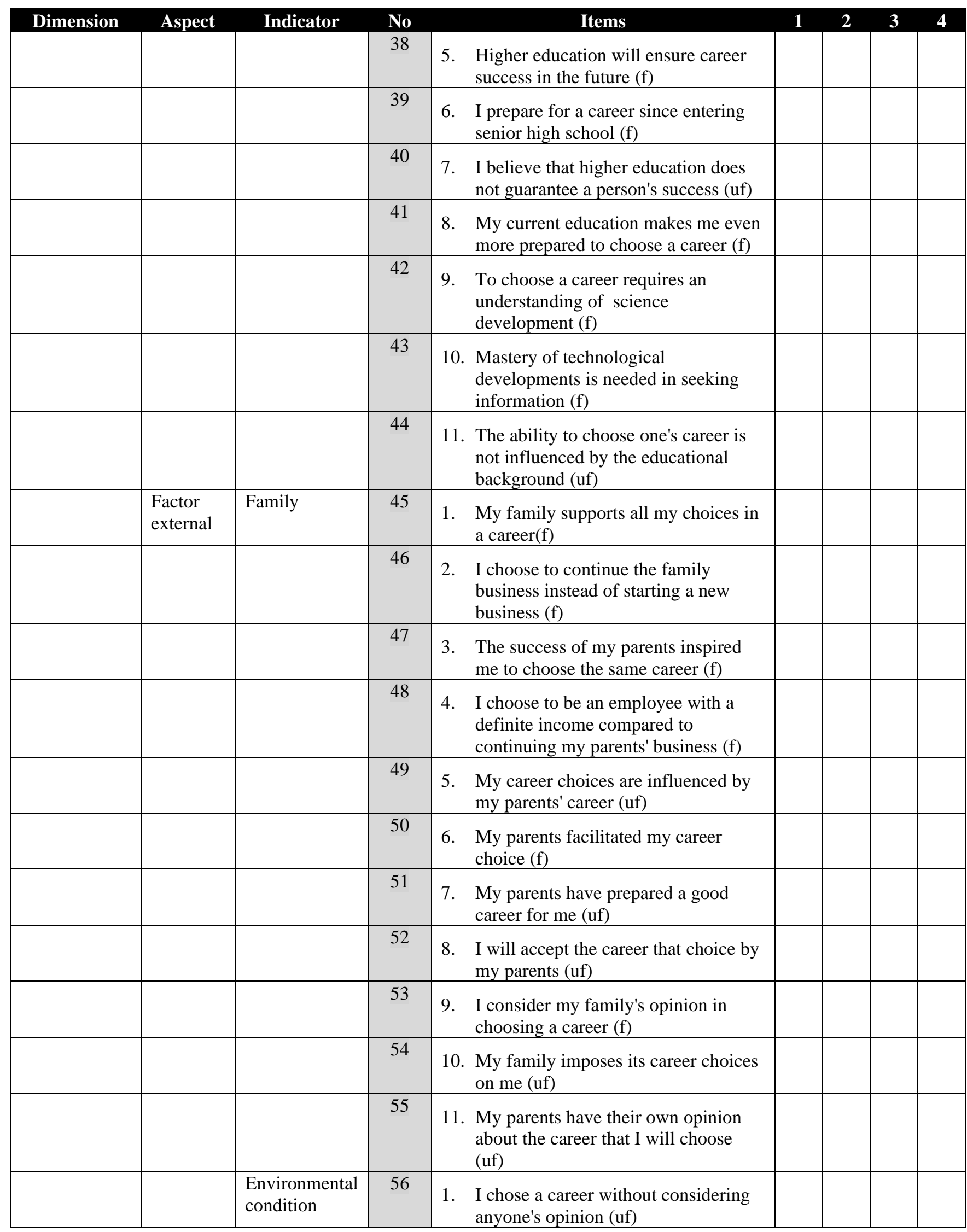




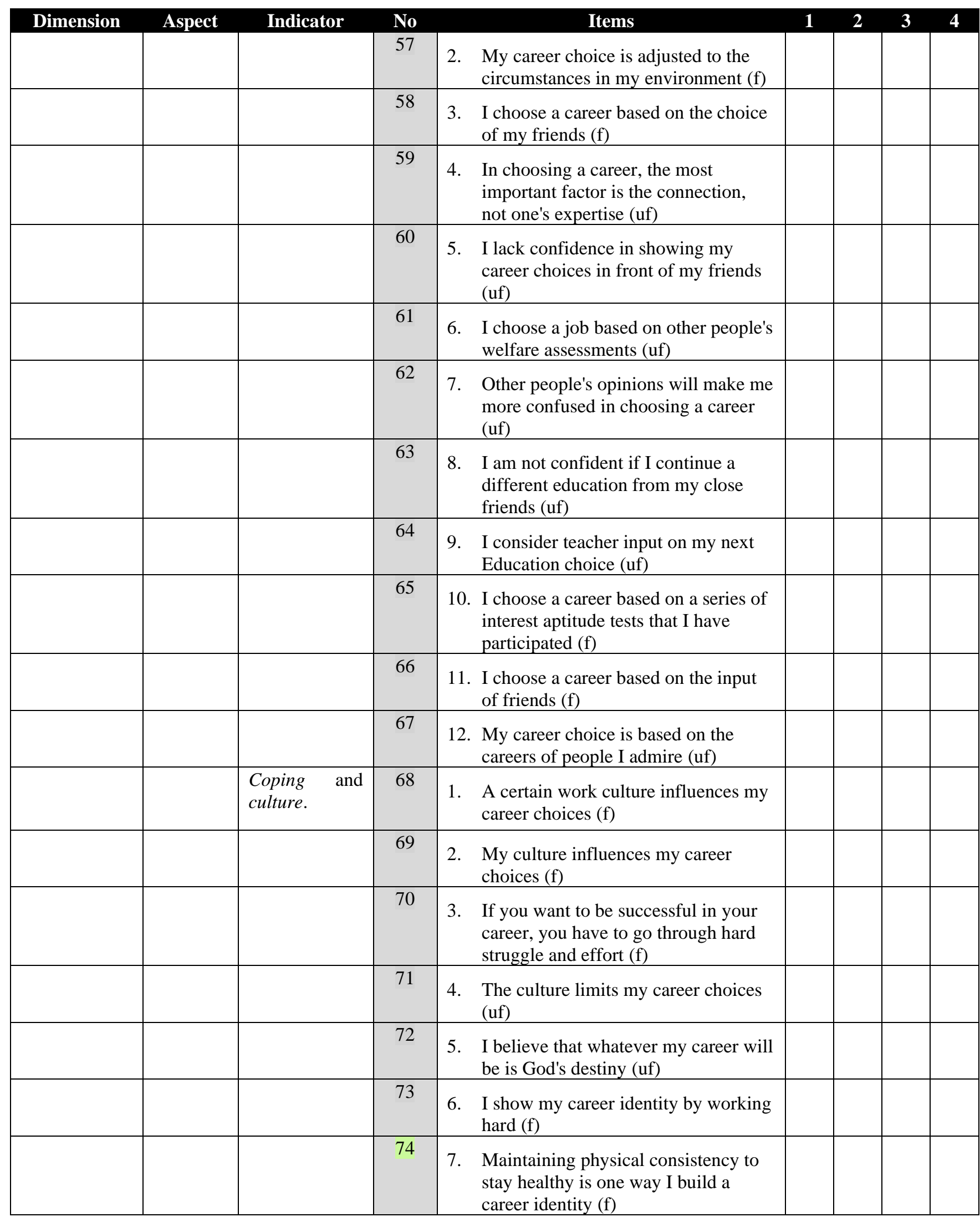




\begin{tabular}{|c|c|c|c|c|c|c|c|c|}
\hline Dimension & Aspect & Indicator & No & Items & 1 & 2 & 3 & 4 \\
\hline & & & 75 & $\begin{array}{l}\text { 8. The fieldwork environment makes } \\
\text { me more enthusiastic in working } \\
\text { because I meet and do activities with } \\
\text { many people (f) }\end{array}$ & & & & \\
\hline & & & 76 & $\begin{array}{l}\text { 9. I am not bothered by work that uses a } \\
\text { seniority system because it is a } \\
\text { challenge in itself (f) }\end{array}$ & & & & \\
\hline & & & 77 & $\begin{array}{l}\text { 10. I am diligent in exercising to prepare } \\
\text { for continuing education in secondary } \\
\text { schools that contain military elements } \\
\text { (f) }\end{array}$ & & & & \\
\hline & & & 78 & $\begin{array}{l}\text { 11. I will try and work hard to be at the } \\
\text { top position in my job (f) }\end{array}$ & & & & \\
\hline & & & 79 & $\begin{array}{l}\text { 12. I choose to resign instead of having } \\
\text { to endure a job that is not under my } \\
\text { passion (uf) }\end{array}$ & & & & \\
\hline
\end{tabular}

Note: 1: Strongly disagree, 2: Disagree, 3: Agree, 4: Strongly Agree. 